\title{
A comparison of dietary habits among women in Japan and Hawaii
}

\author{
Yumie Takata ${ }^{1}$, Gertraud Maskarinec ${ }^{1, *}$, Adrian Franke ${ }^{1}$, Chisato Nagata ${ }^{2}$ \\ and Hiroyuki Shimizu ${ }^{2}$ \\ ${ }^{1}$ Cancer Research Center of Hawaii, 1236 Lauhala Street, Honolulu, HI 96813, USA: \\ ${ }^{2}$ Gifu University School of Medicine, Gifu, Japan
}

Submitted 1 April 2003: Accepted 19 August 2003

\begin{abstract}
Objective: To compare the dietary habits of Japanese women in Japan with those of Japanese and Caucasian women living in Hawaii.

Design: Data from two previous cross-sectional studies conducted within two years in Hawaii and Gifu, Japan were pooled and analysed. Dietary intakes were assessed with validated food-frequency questionnaires and urine samples were collected for isoflavone measurement.

Setting: Participants were recruited through mammography clinics in both locations. Subjects: In Hawaii, 164 Caucasian and 146 Japanese women; in Japan, 206 women. Results: Dietary habits differed considerably by ethnicity and location. In comparison to the Caucasian diet, the diet in Japan was relatively low in fat and high in carbohydrates and protein, whereas the Japanese women in Hawaii reported intermediate intakes. Japanese women in Gifu consumed a diet that was relatively high in fish, soy, eggs and vegetables, and low in fruits, dairy products and meat. In contrast, the Caucasian women consumed the most dairy products and fruits and the Japanese women in Hawaii reported the highest grain and meat intakes.

Conclusions: The diet of Japanese women in Hawaii appeared to be a combination of foods eaten in Japan and the dietary habits of Caucasian women in Hawaii, but eating habits in Japan are also different from traditional nutritional patterns. This study illustrates several problems related to dietary comparisons across populations and provides information for future investigations on chronic disease risk.
\end{abstract}

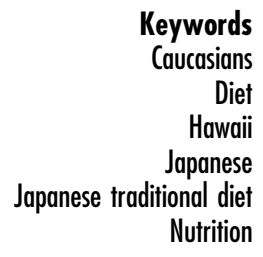

Although the risk of chronic diseases differs greatly by country and ethnicity ${ }^{1}$, a limited number of epidemiological studies have been conducted among multiple populations. Evidence from populations with different eating habits may contribute to the understanding of diet and disease risk ${ }^{2}$ because of the wide variation in nutritional intake between geographic areas as compared with that in a small homogeneous population. The importance of nutrition in the development of chronic diseases has been demonstrated repeatedly ${ }^{3-5}$. For example, the increasing colon cancer risk among the Japanese population in Hawaii has been associated with red meat consumption ${ }^{6,7}$ and the rising incidence of heart disease and the decreasing occurrence of stroke appear to be related to changes in dietary fat and salt intakes ${ }^{8,9}$. Changing nutritional patterns have been described for many migrant populations, but the Japanese have been of particular interest because of the dramatic changes in incidence of cancer and cardiovascular disease. More years in the USA were associated with a more Westernised diet among Chinese, Korean and Mexican American migrants ${ }^{10}$ and a higher degree of acculturation was related to a higher percentage of dietary fat among Japanese Americans ${ }^{11}$. Looking at different generations ${ }^{12}$, Nisei (second-generation Japanese Americans) consumed Japanese foods more frequently, whereas Sansei (thirdgeneration Japanese Americans) consumed less rice and more Western foods. Under the influence of Westernisation, improvements in the economy and food imports ${ }^{13}$, the diet in Japan has also been changing. Over the last 50 years, intakes of milk, meats, oils, fats and fruits have been increasing, while the intake of rice has decreased ${ }^{14}$. The consumption of fish, green and yellow vegetables, and beans has remained constant. At the same time, the Asian population in Hawaii made Asian foods, including Japanese foods, available to Caucasians in Hawaii.

The approach of using ecological data from nutrition surveillance systems for these comparisons is limited by methodological problems. For example, the national nutrition surveillance in the USA (the Continuing Survey of Food Intakes by Individuals) uses dietary recalls, whereas the Japanese programme collects food records. The crude approach of food balance sheets is not suitable to estimate average dietary consumption for individuals ${ }^{2}$. 
As an alternative, pooled analyses provide a unique opportunity to compare dietary data across populations ${ }^{2}$. This current study compared diet among Japanese women in Japan with that of Japanese and Caucasian women in Hawaii and examined dietary differences among the three groups.

\section{Methods}

\section{Study population}

We pooled data from two previous cross-sectional studies that analysed dietary and mammographic characteristics in Hawaii $^{15}$ and Japan ${ }^{16}$. The study in Hawaii recruited 157 women of Japanese and 187 women of Caucasian ancestry through two mammography clinics in 1997/98. The study in Japan enrolled 212 Japanese women from Gihoku General Hospital in Gifu City, Japan, in 1998/99. All women had never been diagnosed with breast cancer, had no history of breast surgery, and had no suspicious lesions in their screening mammogram at the time of the study. Complete information was available for 165 Caucasian women in Hawaii, 145 Japanese women in Hawaii and 206 Japanese women in Japan. Three Caucasian women and four Japanese women in Japan were excluded from dietary analysis because their self-reported daily energy intake was outside the plausible range of 600-6000 kcal.

\section{Data collection}

Information on demographic, anthropometric and reproductive characteristics, as well as medical history, were collected with a food-frequency questionnaire (FFQ). Body mass index (BMI) was calculated from self-reported body weight and height in the questionnaire. For women in Hawaii, in addition to country of birth and total years in the USA, the participants marked all applicable ethnicities out of nine categories for themselves and their parents. Japanese women in Gifu completed a validated FFQ containing 169 food items ${ }^{17}$, including nine soy food questions. Japanese and Caucasian women in Hawaii were provided with a validated FFQ designed for a multiethnic population containing 188 food items ${ }^{18}$ and with a separate soy FFQ containing 10 soy food questions $^{19}$. The FFQs in Hawaii and Japan were developed under the guidance of Dr Jean Hankin. Food records and dietary recalls were used to capture the majority of locally consumed foods. Both self-administered FFQs asked about the frequency of intake of food items, including a large number of mixed dishes, and their usual portion sizes during the past year. The layout in both FFQs had eight frequency categories and three different portion sizes shown in photographs to aid estimation. In validation studies, both questionnaires appeared to have a better correlation with other dietary methods when intakes were adjusted for energy intake ${ }^{17,18}$. We minimised missing dietary information by re-contacting the participants when they had skipped parts of the FFQ. For the analysis, mixed dishes were decomposed into their ingredients. The nutrient composition was based on the food composition tables from the US Department of Agriculture $^{20}$ and local recipes for the Hawaii data, and on the Standard Tables of Food Composition in Japan ${ }^{21}$ for the Gifu data. The calculation of isoflavone intake from soy foods was based on published data in each location $^{22,23}$.

\section{Urine sample collection}

Overnight urine (first urine in the morning) was collected for a randomly selected sample of participants in Hawaii (response rate $78 \%)^{19}$. All women in Japan provided a spot urine (one sample collected during the clinic visit) ${ }^{24}$. All urine samples from women in Japan and Hawaii were analysed at the Cancer Research Center of Hawaii using high-pressure liquid chromatography with diode-array detection $^{19}$. The sum of the separately measured isoflavones, including daidzein, genistein, glycitein and their main metabolites, O-desmethylangolensin and equol, constituted the total urinary isoflavone excretion. To adjust for urine volume, the isoflavone values were expressed in relation to creatinine concentrations of the urine.

\section{Assessment of total energy intake}

Because under- and overreporting of dietary intake is a common issue in nutritional data ${ }^{2}$, we compared selfreported intake and estimated energy intake (EEI). We calculated the basal metabolic rate according to the 1985 Food and Agriculture Organization/World Health Organization/United Nations University report ${ }^{25}$ and multiplied the result with the appropriate factor for physical activity using the Goldberg equation ${ }^{26,27}$. Due to the lack of physical activity information in the Gifu data, we assumed that the level was lightly active for all women.

\section{Dietary comparison}

We used percentages of energy intake from macronutrients and nutrient and food group intakes per $1000 \mathrm{kcal}$ to compare nutritional parameters among the three groups of women. This energy-adjusted method has the advantages of describing the composition of diets and correcting for under- and overreporting of total energy intake $^{2}$. Owing to differences in each country's food composition table, some nutrient values are based on the standards used in the USA, while others are based on those used in Japan. For example, vitamin A intake was expressed as IU (International Unit) instead of RE (retinol equivalent) in Japan. Because of incompatible nutrient values in the datasets, intakes of fibre and types of fat (i.e. saturated, monounsaturated and polyunsaturated fat) had to be excluded. The percentages of energy from macronutrients in the Hawaii dataset were based on the method of the Atwater system ${ }^{28}$ that calculates the available energy after subtracting energy loss resulting 
from digestion and metabolism. In contrast, these percentages in the Gifu dataset were based on $4 \mathrm{kcal}$ per gram for protein and carbohydrates, $9 \mathrm{kcal}$ per gram of fat, and $7 \mathrm{kcal}$ per gram of ethanol. Food items were grouped into nine food groups according to the Japanese system (see Appendix), where each food item belongs to only one group and the intake from each group is measured in grams. For foods that were grouped differently in the two locations, we made them as comparable as possible, but sometimes they had to remain classified according to the local custom. For instance, biscuits, some doughnuts and Danish pastry were grouped as 'bread' in Hawaii, while the Gifu dataset grouped them into the 'sugar and sweets' group.

\section{Statistical analysis}

In order to compare descriptive and dietary characteristics among the three groups of women, analysis of variance with the GLM procedure in SAS was performed for continuous variables, and chi-square tests and likelihood ratios were used for categorical variables ${ }^{29}$. The Duncan post hoc test was used for further comparison between groups. Variables were converted into the same format in the two datasets. For non-normally distributed variables, we used a logarithmic or square-root transformation or created categories (quartiles) to meet the assumption of normality. When variables were categorised into quartiles, a mean value for each quartile was used in the analyses. All statistical analyses were performed using SAS, release 8.02 (SAS Institute, Cary, NC, USA).

\section{Results}

\section{Characteristics of the study population}

Caucasian women in Hawaii had a greater height, weight and BMI than did Japanese women in Hawaii and Gifu, but Japanese women in Hawaii and Gifu had very similar anthropometric characteristics (Table 1). Caucasians were close to 4 years older than the Japanese in Gifu; Japanese in Hawaii were intermediate in age. Few women in any group were currently smoking. More than 90\% of Japanese women in Hawaii reported pure Japanese ethnicity and were second- or third-generation Japanese Americans. Within this group of women, $94 \%$ were born in the USA and $5 \%$ were born in Japan. Only $2 \%$ had lived in the USA for less than 26 years. Among Caucasian women in Hawaii, 6\% were born outside the USA and approximately $3 \%$ of them had lived in the USA for less than 26 years.

\section{Nutrient intakes}

Japanese women in Gifu (Table 2) reported the highest mean energy intake, followed by Japanese and Caucasian women in Hawaii, although their average body weight was lower than that of Caucasian women. The EEI results indicated a difference in underreporting of total energy among the three groups of women. The reported energy intake of Japanese women in Gifu (2239 kcal) agreed with their EEI of $2235 \mathrm{kcal}$. In contrast, Japanese and Caucasian women in Hawaii underreported their energy intake by 200 and $500 \mathrm{kcal}$, respectively (EEI of 2253 and $2411 \mathrm{kcal}$, respectively).

Nutritional intakes differed significantly by ethnicity and location (Table 2). The Gifu women reported the lowest percentage of energy from fat and the highest percentage of energy from carbohydrates. The percentages in the Caucasian women were exactly reversed (highest fat and lowest carbohydrates), while the Japanese women in Hawaii were intermediate for both macronutrients. All three groups consumed a very low percentage of energy from ethanol, but Caucasian women reported the greatest intake, approximately $8.2 \mathrm{~g} \mathrm{day}^{-1}$. All women in Hawaii tended to follow a diet with higher fat and slightly lower

Table 1 Characteristics of the study population

\begin{tabular}{lcccc}
\hline Characteristic & $\begin{array}{c}\text { Japanese } \\
\text { in Gifu }\end{array}$ & $\begin{array}{c}\text { Japanese } \\
\text { in Hawaii }\end{array}$ & $\begin{array}{c}\text { Caucasians } \\
\text { in Hawaii }\end{array}$ & $P$-value \\
\hline Number of participants & 206 & 145 & 165 & - \\
Age (years) & $50.0(9.1)$ & $52.3(9.7)$ & $53.7(9.9)$ & 0.0010 \\
Years of education & $11.9(2.0)$ & $16.2(2.8)$ & $16.3(3.1)$ & $<0.0001$ \\
Age at menarche (years) $\dagger$ & $13.2(1.5)$ & $12.2(1.5)$ & $12.5(1.5)$ & $<0.0001$ \\
Number of children & $2.3(0.8)$ & $1.9(1.4)$ & $1.6(1.6)$ & $<0.0001$ \\
Number of premenopausal women & 106 & 69 & 73 & - \\
Number of postmenopausal women & 100 & 76 & 92 & - \\
Age at menopause (years) & $48.8(4.1)$ & $47.2(5.8)$ & $46.8(5.7)$ & 0.0237 \\
History of oestrogen use (\%) & 9.0 & 77.6 & 80.4 & $<0.0001$ \\
Currently smoking (\%) & 6.4 & 4.8 & 5.5 & $<0.0001$ \\
Body mass index (kg m $\left.{ }^{-2}\right) \dagger$ & $23.1(3.0)$ & $23.1(3.9)$ & $24.9(4.8)$ & $<0.0001$ \\
Height (cm) $\ddagger$ & $154.8(5.6)$ & $156.4(5.4)$ & $164.2(6.9)$ & $<0.0001$ \\
Body weight $(\mathrm{kg})$ & $55.4(7.9)$ & $56.6(10.1)$ & $67.3(13.4)$ & $<0.0001$ \\
\hline
\end{tabular}

The numbers in parentheses are standard deviation.

* For continuous variables, analysis of variance was used for testing. For categorical variables, chi-square tests and likelihood ratios were applied. $P$-values indicate significant differences across all three groups.

† Logarithmic transformation was used for significance testing due to non-normal distribution.

‡ Square-root transformation was used for significance testing due to non-normal distribution. 
Table 2 Dietary characteristics of the study population. Values are expressed as means (standard deviation)

\begin{tabular}{|c|c|c|c|c|}
\hline Nutrient & $\begin{array}{l}\text { Japanese } \\
\text { in Gifu }\end{array}$ & $\begin{array}{l}\text { Japanese } \\
\text { in Hawaii }\end{array}$ & $\begin{array}{c}\text { Caucasians } \\
\text { in Hawaii }\end{array}$ & $P$-value \\
\hline \multicolumn{5}{|l|}{ Nutrients } \\
\hline Energy intake (kcal)† & $2239(760)$ & $2032(881)$ & $1920(691)$ & 0.0005 \\
\hline Protein (g/1000 kcal) & $41.1(5.6)$ & $36.2(6.0)$ & $37.3(5.9)$ & $<0.0001$ \\
\hline Fat $(g / 1000 \mathrm{kcal})$ & $28.6(4.9)$ & $33.6(7.4)$ & $34.5(7.1)$ & 0.0030 \\
\hline Carbohydrates (g/1000 kcal) & $138.5(15.6)$ & $140.8(22.3)$ & $133.4(21.9)$ & $<0.0001$ \\
\hline Cholesterol (mg/1000 kcal) & $152.3(49.7)$ & $97.2(35.6)$ & $105.4(35.6)$ & $<0.0001$ \\
\hline Ethanol $(\mathrm{g} / 1000 \mathrm{kcal})$ & $1.8(4.0)$ & $1.3(3.4)$ & $4.7(6.9)$ & $<0.0001$ \\
\hline Calcium (mg/1000 kcal)† & $350.0(114.8)$ & $376.2(117.9)$ & $494.4(162.8)$ & $<0.0001$ \\
\hline Phosphorus (mg/1000 kcal) & $646.1(96.3)$ & $605.7(87.6)$ & $692.7(121.6)$ & $<0.0001$ \\
\hline Iron $(\mathrm{mg} / 1000 \mathrm{kcal}) \ddagger$ & $6.4(1.6)$ & $8.2(3.9)$ & $9.9(5.6)$ & $<0.0001$ \\
\hline Sodium (mg/1000 kcal) & 2585 (537) & $1445(293)$ & $1442(296)$ & $<0.0001$ \\
\hline Vitamin A (IU /1000 kcal)† & 2046 (1413) & 6481 (4472) & 7458 (4379) & $<0.0001$ \\
\hline Thiamin (mg/1000 kcal) $\ddagger$ & $0.5(0.1)$ & $0.8(0.3)$ & $0.9(0.3)$ & $<0.0001$ \\
\hline Riboflavin $(\mathrm{mg} / 1000 \mathrm{kcal}) \ddagger$ & $0.7(0.2)$ & $0.9(0.3)$ & $1.1(0.4)$ & $<0.0001$ \\
\hline Vitamin C $(\mathrm{mg} / 1000 \mathrm{kcal}) \dagger$ & $64.3(34.7)$ & $81.1(47.7)$ & $89.7(42.1)$ & $<0.0001$ \\
\hline Vitamin $\mathrm{E}(\mathrm{mg} \alpha-\mathrm{TE} / 1000 \mathrm{kcal}) \ddagger$ & $4.1(1.1)$ & $7.5(4.4)$ & $8.1(5.2)$ & $<0.0001$ \\
\hline Soy protein $(\mathrm{g} / 1000 \mathrm{kcal}) \dagger$ & $2.7(1.7)$ & $2.3(2.7)$ & $1.2(2.4)$ & $<0.0001$ \\
\hline Isoflavone $(\mathrm{mg} / 1000 \mathrm{kcal}) \dagger$ & $11.6(6.4)$ & $7.2(9.4)$ & $3.5(7.7)$ & $<0.0001$ \\
\hline \multicolumn{5}{|c|}{ Percentage of energy from macronutrients } \\
\hline Fat $(\%)$ & $25.8(4.4)$ & $29.7(6.7)$ & $30.3(6.5)$ & $<0.0001$ \\
\hline Protein (\%) & $16.4(2.2)$ & $14.2(2.4)$ & $14.6(2.3)$ & $<0.0001$ \\
\hline Carbohydrates (\%) & $55.4(6.2)$ & $55.2(8.4)$ & $51.9(8.0)$ & $<0.0001$ \\
\hline Ethanol $(\%) \ddagger$ & $1.3(2.8)$ & $0.9(2.3)$ & $3.2(4.7)$ & $<0.0001$ \\
\hline \multicolumn{5}{|l|}{ Food groups } \\
\hline Grains (g/1000 kcal)† & $151.8(31.6)$ & $220.1(71.3)$ & $155.2(65.9)$ & $<0.0001$ \\
\hline Fish $(\mathrm{g} / 1000 \mathrm{kcal}) \dagger$ & $41.3(17.7)$ & $10.6(7.2)$ & $10.5(8.9)$ & $<0.0001$ \\
\hline Meats $(\mathrm{g} / 1000 \mathrm{kcal}) \S$ & $35.5(17.5)$ & $64.5(32.7)$ & $57.5(34.0)$ & $<0.0001$ \\
\hline Eggs $(\mathrm{g} / 1000 \mathrm{kcal}) \dagger$ & $19.9(9.6)$ & $5.5(4.6)$ & $5.8(5.6)$ & $<0.0001$ \\
\hline Dairy products $(\mathrm{g} / 1000 \mathrm{kcal}) \S$ & $95.8(85.2)$ & $128.9(91.4)$ & $194.5(123.0)$ & $<0.0001$ \\
\hline Vegetables $(\mathrm{g} / 1000 \mathrm{kcal}) \dagger$ & $195.9(115.8)$ & $124.2(83.6)$ & $137.9(69.1)$ & $<0.0001$ \\
\hline Seaweed $(\mathrm{g} / 1000 \mathrm{kcal}) \ddagger$ & $13.2(11.8)$ & $0.7(0.7)$ & $0.2(0.5)$ & $<0.0001$ \\
\hline Fruits $(\mathrm{g} / 1000 \mathrm{kcal}) \dagger$ & $58.8(39.6)$ & $119.1(101.5)$ & $128.7(91.8)$ & $<0.0001$ \\
\hline Soy products $(\mathrm{g} / 1000 \mathrm{kcal}) \dagger$ & $28.9(21.9)$ & $19.2(27.3)$ & $2.0(29.6)$ & $<0.0001$ \\
\hline
\end{tabular}

$\alpha$-TE $-\alpha$-tocopherol equivalents.

${ }^{*}$ Analysis of variance was used for significance testing across groups.

$\dagger$ Logarithmic transformation was used for significance testing.

$\ddagger$ Categorised into quartiles and a mean value of the quartile was used for significance testing.

$\S$ Square-root transformation was used for significance testing.

protein than women in Gifu, whereas Japanese women in Hawaii and Gifu tended to have a higher proportion of carbohydrates in their diet than Caucasian women. For other nutrients, intakes of sodium, isoflavone and cholesterol were highest among Japanese women in Gifu; their isoflavone intake was almost three times higher than that of Caucasian women. Calcium, phosphorus, iron, vitamin $\mathrm{A}$, thiamin, riboflavin and vitamins $\mathrm{C}$ and $\mathrm{E}$ were consumed more by Caucasian women than by women in either Japanese group. With the exception of phosphorus, intakes of micronutrients among Japanese women in Hawaii were intermediate between those of Japanese women in Gifu and Caucasian women.

\section{Food group intakes}

In comparison to that in Hawaii, the diet in Gifu was high in fish ( 4.5 times higher than in Hawaii), eggs (four times higher than in Hawaii), soy products, vegetables and seaweed, and low in meat, dairy products and fruits. Caucasian women consumed the most fruits and dairy products, approximately twice as much as the women in
Gifu. Both groups in Hawaii reported high in fruits and low in fish, eggs and seaweed, but Japanese women in Hawaii reported slightly higher soy and lower dairy products than Caucasian women. Intakes of dairy products except whole milk were higher in Caucasian than Japanese women in Hawaii. Japanese women in Hawaii showed several interesting characteristics: grain intake was nearly 50\% higher than in the other two groups; meat intake was 10\% higher than in Caucasians and nearly twice as high as in Japan; and vegetable consumption was lower than in the two other groups. The extraordinarily high grain intake among Japanese women in Hawaii was primarily due to rice. It contributed $57 \%$ of the grain intake, whereas it accounted for only $27 \%$ of grains among Caucasian women. On the other hand, bread and pasta intakes were comparable in the two groups. The intake of red meat among Japanese women in Hawaii accounted for $32 \%$ of total meat intake, while it was only $25 \%$ among Caucasian women. In summary (Table 3), the Japanese women in Gifu consumed a diet that was relatively high in fish, soy, eggs and vegetables, and low in fruits, dairy 
Table 3 Summary of dietary characteristics by group of women

\begin{tabular}{|c|c|c|c|c|}
\hline Group & $\begin{array}{l}\text { High nutrient } \\
\text { intakes* }\end{array}$ & $\begin{array}{l}\text { Low nutrient } \\
\text { intakes* }^{*}\end{array}$ & High food intakes* & Low food intakes* \\
\hline Japanese in Gifu & $\begin{array}{l}\text { Protein } \\
\text { Cholesterol } \\
\text { Sodium } \\
\text { Soy protein } \\
\text { Isoflavones }\end{array}$ & $\begin{array}{l}\text { Fat } \\
\text { Calcium } \\
\text { Iron } \\
\text { Vitamins }\end{array}$ & $\begin{array}{l}\text { Fish } \\
\text { Eggs } \\
\text { Vegetables } \\
\text { Seaweed } \\
\text { Soy products }\end{array}$ & $\begin{array}{l}\text { Fruits } \\
\text { Dairy products } \\
\text { Grains } \\
\text { Meats }\end{array}$ \\
\hline Japanese in Hawaii & Carbohydrates & $\begin{array}{l}\text { Cholesterol } \\
\text { Ethanol } \\
\text { Phosphorus }\end{array}$ & $\begin{array}{l}\text { Grains } \\
\text { Meats }\end{array}$ & $\begin{array}{l}\text { Eggs } \\
\text { Fish }\end{array}$ \\
\hline Caucasians in Hawaii & $\begin{array}{l}\text { Ethanol } \\
\text { Vitamins } \\
\text { Calcium } \\
\text { Phosphorus } \\
\text { Iron }\end{array}$ & Carbohydrates & $\begin{array}{l}\text { Dairy products } \\
\text { Fruits }\end{array}$ & $\begin{array}{l}\text { Seaweed } \\
\text { Fish } \\
\text { Soy products }\end{array}$ \\
\hline
\end{tabular}

* In all columns, intakes that are significantly different from the other two groups based on the Duncan post hoc test are shown in italics.

products and meat. On the other hand, the diets of Caucasian women were comparably high in dairy products and fruit and the Japanese women in Hawaii reported the highest grain and meat intakes.

\section{Urinary isoflavone excretion}

Urine samples were available for 193 Japanese women in Gifu and for 40 Caucasian and 23 Japanese women in Hawaii. The mean urinary excretion rate was highest $(61.2 \mathrm{nmol} / \mathrm{mg}$ creatinine) among Japanese women in Gifu, followed by Japanese and Caucasian women in Hawaii (17.8 and $3.4 \mathrm{nmol} / \mathrm{mg}$ creatinine, respectively). Among all women with isoflavone measurements, the correlation between urinary isoflavone excretion and reported isoflavone intake was $0.52(P \leq 0.0001)$.

\section{Discussion}

Each group of women in our study had a distinct dietary composition with respect to nutrients and food groups. Overall, the diet of Japanese women in Hawaii appeared like a combination of the two other diets (Table 2). This tendency was apparent in the percentages of energy from fat and carbohydrates: the percentage from fat was similar to the diet in Gifu and the percentage from carbohydrates was comparable to Caucasians' intake. In contrast, their intakes of micronutrients and food items were similar to the patterns in Caucasian women. Altogether, the diet of Japanese women in Hawaii resembled the Caucasian diet more than the Gifu diet because the levels of key nutrient and food intakes, such as vitamins, sodium, iron, eggs, fish and fruits, were similar.

The Caucasian diet was characterised by high intakes of dairy products and fruits, while intakes of fish, eggs, seaweed and soy products were low. The fat intake among Caucasian women in our study meets the dietary guidelines and is considered moderate ${ }^{30}$. Although Caucasian women reported the highest ethanol intake (8.2 $\mathrm{g} \mathrm{day}^{-1}$, approximately equal to one serving of beer), their intake level is within the range of national recommendations ${ }^{30}$. It is noteworthy that this population of primarily second- or third-generation Japanese migrants has not adopted the high dairy intake of the Caucasian women, but has exceeded their meat intake. In contrast to the Multiethnic Cohort Study ${ }^{31}$, Caucasian and Japanese women in our study had somewhat higher micronutrient and fish intakes. We found lower protein and fat intakes per $1000 \mathrm{kcal}$, higher intakes of vitamin C and E, and twice as high an intake of vitamin A as a study among women of different ethnicity in the $\mathrm{USA}^{32}$. The relatively high salt intake among women in Gifu $(6.8 \mathrm{~g} / 1000 \mathrm{kcal})$ is considered average in Japan $(6.4 \mathrm{~g} / 1000 \mathrm{kcal})^{13}$. Egg consumption in this study is similar to what is recommended in Japan because of the beneficial amino acid profile in eggs. The high intake of fish in Gifu is consistent with other reports ${ }^{12,14}$. When we compared our results with those from a large cohort study in a rural community $^{33}$, we found a higher energy intake $(2239 \mathrm{kcal}$ vs. $2117 \mathrm{kcal}$ ) and a $27 \%$ higher intake of vitamin A per $1000 \mathrm{kcal}$ in Gifu, but otherwise similar nutrient intakes.

Using percentage of energy from carbohydrates and fat as an indicator, a reciprocal trend in the two macronutrients can be observed. The Japanese women in the rural cohort $^{33}$ reported one of the highest carbohydrate intakes and the lowest fat content $(57 \%$ and $24 \%$, respectively), followed by the Japanese women in Gifu (55\% and 26\%), Japanese Americans in the Multiethnic Cohort (58\% and 29\%) $)^{31}$ and our Japanese women in Hawaii (55\% and 30\%). The percentages among Caucasian women in Hawaii (52\% and 30\%) and in Caucasian women in the Multiethnic Cohort (54\% and $31 \%)^{31}$ were similar and close to the diet of the population in the USA $(52 \% \text { and } 32 \%)^{34}$. In a similar study from Brazil, the percentages of energy from carbohydrates and fat among Japan-born Japanese Brazilian women were 54\% and 33\%, respectively ${ }^{35}$. Although these discrepancies can still be observed, one should keep in mind that during the $1950 \mathrm{~s}$ the percentages of energy from carbohydrates and fat 
in the Japanese diet were estimated at $78 \%$ and $9 \%$, respectively ${ }^{36}$. An intake of vitamin A higher than the recommended amount was noteworthy in the Hawaii diet. It may reflect a high consumption of vegetables and tropical fruits in Hawaii (e.g. one medium mango has approximately 2600 IU) or a high intake of fortified foods $^{37}$, which are uncommon in Japan. The major similarity between the diet of Japanese women in Hawaii and in Gifu was calcium intake, which is consistent with the consumption of dairy products. In the American food system, food rich in calcium is often rich in phosphorus as well. However, the high phosphorus in Gifu was probably derived from a different food source than in Hawaii. The 4th edition of the Japanese food composition tables listed a relatively high content of phosphorus for the commonly consumed raw well-milled white rice. Since our study was completed, the phosphorus value has been revised from $140 \mathrm{mg}$ per $100 \mathrm{~g}$ of rice to $94 \mathrm{mg}^{38}$.

The relatively low BMI of Japanese American women was comparable to findings in the Multiethnic Cohort $\left(23.6 \mathrm{~kg} \mathrm{~m}^{-2}\right)^{31}$ and in a study from Seattle $\left(23.1 \mathrm{~kg} \mathrm{~m}^{-2}\right)^{39}$. The BMI of our Gifu women was also similar to the national average in Japan for women aged 40-59 years $\left(23.2 \mathrm{~kg} \mathrm{~m}^{-2} \text { in 2000) }\right)^{40}$. The majority of the Japanese women in Hawaii in our study were born in the USA and had lived there all their lives. However, they maintained a similar BMI to women in Japan although their diet was closer to that of Caucasian women in Hawaii than to the diet of Japanese women in Gifu. This finding is confirmed by a study among Japanese Brazilian women who maintained the same BMI as in Japan despite their high percentage of energy from fat ${ }^{35}$. This suggests that other factors related to ethnicity may influence body size more than the foods consumed regularly. The ethnic differences in body size could be a result of nutrition in early life, as recent studies propose that soy intake during adolescence affects breast cancer risk during adulthood ${ }^{41,42}$.

The strength of our study is that we were able to compare the characteristics of women who differed by ethnicity and place of residence. Because both FFQs were developed with the same methodology and advice from an experienced nutritionist ${ }^{17,18}$, they shared many common features, such as the type of questions, the presentation of serving sizes and the inclusion of mixed dishes. However, there were also several limitations in our study. As noted in the European Prospective Investigation into Cancer and Nutrition, differences in nutrient database and food composition tables introduce a number of problems into the comparison of diets from different populations ${ }^{43}$. It appeared that women in Hawaii underreported their dietary intakes, but the lack of information on physical activity among Gifu women did not allow a more detailed comparison. It is unlikely that the relatively higher energy intake in Gifu is due to higher physical activity levels rather than underreporting of energy intake in Hawaii. However, it may have been difficult for women in Hawaii to find corresponding categories for all food items that they consumed regularly. The Hawaii FFQ had to limit the number of ethnic-specific foods because it was designed to include common foods for five different ethnic groups, whereas the FFQ in Gifu was developed specifically for a Japanese population. The higher BMI and the desire to comply with societal norms may also be responsible for underreporting energy intake among Caucasians $^{2}$. Some food groups and nutrient values were not fully comparable because of different food grouping systems used in the USA and Japan. Likewise, the values in each country's food composition tables are based on different chemical analyses, conversion factors and definitions ${ }^{43}$, but we restricted our analysis to comparable nutrient values. Although the urinary isoflavone assessment confirmed the validity of soy consumption measured by the FFQ, as reported by previous studies ${ }^{19,24,44}$, the difference in mean urinary isoflavone excretion between groups was considerably greater than the difference in self-reported soy intake. Most likely, this was a result of the fact that women in Gifu donated a urine sample when they visited the clinic in the morning. Since tofu and miso soup are commonly eaten for breakfast in Japan, the urine collection captured the time when isoflavone excretion was at its peak, whereas the women in Hawaii collected urine in the morning when isoflavone excretion was much lower due to the short half-life.

In summary, we showed that the dietary patterns of Japanese women in Hawaii are a mixture of the dietary characteristics observed among Caucasian women and women in Japan. The high meat intake in Japanese Americans has been observed before and appears to be related to colorectal cancer ${ }^{6,7}$. The rising mortality rate for colon cancer in Japan may be linked to similar changes in dietary patterns ${ }^{45}$. High intakes of fish, vegetables, sodium and isoflavones, confirmed by urinary measurements, appeared to be typical for the Japanese diet, whereas high intakes of fruits and vitamin A seemed to characterise the diet in Hawaii. Food and nutrient intakes among the Gifu women illustrate how traditional Japanese dietary patterns are declining and Western food consumption is increasing $^{36}$. The effect of changing eating habits on the incidence rates of chronic diseases, such as soy intake on the risk of prostate ${ }^{46}$ and breast cancer ${ }^{4}$, will offer interesting opportunities for research in the future.

\section{Acknowledgements}

The National Cancer Institute (R03 CA 81620) and the US Army Medical Research and Medical Command (DAMD1796-6284) supported this study. We would like to thank all the women who participated in this study for their time and effort. This analysis was part of Yumie Takata's master's thesis in the Department of Human Nutrition, Food and Animal Sciences at the University of Hawaii. We wish to thank the thesis committee members Dr Suzanne 
Murphy and Dr Rachel Novotny for their critical input and Dr Sangita Sharma for helping with the calculation of estimated energy intake.

\section{References}

1 Ferlay J, Bray F, Pisani P, Parkin DM. GLOBOCAN 2000: Cancer Incidence Mortality and Prevalence Worldwide. International Agency for Research on Cancer (IARC) CancerBase No. 5. Lyon: IARC Press, 2001.

2 Willett W. Nutritional Epidemiology. New York: Oxford University Press, 1998.

3 Kolonel LN. Variability in diet and its relation to risk in ethnic and migrant groups. Basic Life Sciences 1988; 43: 129-35.

4 World Cancer Research Fund. Food, Nutrition and The Prevention of Cancer: A Global Perspective. Washington, DC: American Institute for Cancer Research, 1997.

5 Landman J, Cruickshank JK. A review of ethnicity, health and nutrition-related diseases in relation to migration in the United Kingdom. Public Health Nutrition 2001; 4: 647-57.

6 Le Marchand L, Wilkens LR, Hankin JH, Kolonel LN, Lyu LC. A case-control study of diet and colorectal cancer in a multiethnic population in Hawaii (United States): lipids and foods of animal origin. Cancer Causes \& Control 1997; 8: 637-48.

7 Le Marchand L, Hankin JH, Pierce LM, Sinha R, Nerurkar PV, Franke AA, et al. Well-done red meat, metabolic phenotypes and colorectal cancer in Hawaii. Mutation Research 2002; 506-507: 205-14.

8 Yano K, Reed DM, Kagan A. Coronary heart disease, hypertension and stroke among Japanese-American men in Hawaii: the Honolulu Heart Program. Hawaii Medical Journal 1985; 44: 297-321.

9 McGee DL, Reed DM, Yano K, Kagan A, Tillotson J. Ten-year incidence of coronary heart disease in the Honolulu Heart Program. Relationship to nutrient intake. American Journal of Epidemiology 1984; 119: 667-76.

10 Satia-Abouta J, Patterson RE, Neuhouser ML, Elder J. Dietary acculturation: applications to nutrition research and dietetics. Journal of the American Dietetic Association 2002; 102: 1105-18.

11 Huang B, Rodriguez BL, Burchfiel CM, Chyou PH, Curb JD, Yano K. Acculturation and prevalence of diabetes among Japanese-American men in Hawaii. American Journal of Epidemiology 1996; 144: 674-81.

12 Kudo Y, Falciglia GA, Couch SC. Evolution of meal patterns and food choices of Japanese-American females born in the United States. European Journal of Clinical Nutrition 2000; 54: $665-70$.

13 Kida K, Ito T, Yang SW, Tanphaichitr V. Effects of Western diet on risk factors of chronic diseases in Asia. In: Bendich A, Deckelbaum RJ, eds. Preventive Nutrition: The Comprehensive Guide for Health Professionals. Totowa, NJ: Human Press Inc., 2001; 435-46.

14 Tominaga S, Kuroishi T. An ecological study on diet/nutrition and cancer in Japan. International Journal of Cancer 1997; (Suppl. 10): 2-6.

15 Maskarinec G, Meng L, Ursin G. Ethnic differences in mammographic densities. International Journal of Epidemiology 2001; 30: 959-65.

16 Maskarinec G, Nagata C, Shimizu H, Kashiki Y. Comparison of mammographic densities and their determinants in women from Japan and Hawaii. International Journal of Cancer 2002; 102: 29-33.

17 Shimizu H, Ohwaki A, Kurisu Y, Takatsuka N, Ido M, Kawakami $\mathrm{N}$, et al. Validity and reproducibility of a quantitative food frequency questionnaire for a cohort study in Japan. Japanese Journal of Clinical Oncology 1999; 29: $38-44$.

18 Stram DO, Hankin JH, Wilkens LR, Henderson B, Kolonel LN. Calibration of the dietary questionnaire for a multiethnic cohort in Hawaii and Los Angeles. American Journal of Epidemiology 2000; 151: 358-70.

19 Maskarinec G, Singh S, Meng L, Franke AA. Dietary soy intake and urinary isoflavone excretion among women from a multiethnic population. Cancer Epidemiology, Biomarkers EPrevention 1998; 7: 613-19.

20 United States Department of Agriculture (USDA). United States Department of Agriculture Nutrient Database for Standard Reference. Riverdale, MD: USDA, 1993.

21 Committee on Resources, Science Bureau of Japan. Standard Tables of Food Composition in Japan. Tokyo: Printing Office, Ministry of Finance, 1983.

22 Franke AA, Hankin JH, Yu MC, Maskarinec G, Low SH, Custer LJ. Isoflavone levels in soy foods consumed by multiethnic populations in Singapore and Hawaii. Journal of Agricultural and Food Chemistry 1999; 47: 977-86.

23 Wakai K, Egami I, Kato K, Kawamura T, Tamakoshi A, Lin Y, et al. Dietary intake and sources of isoflavones among Japanese. Nutrition and Cancer 1999; 33: 139-45.

24 Seow A, Shi $\mathrm{CH}$, Franke AA, Hankin H, Lee HP, Yu MC. Isoflavonoid levels in spot urine predict frequency of dietary soy intake in a population-based sample of middle-aged Chinese in Singapore. Cancer Epidemiology, Biomarkers \& Prevention 1998; 7: 135-40.

25 Food and Agriculture Organization/World Health Organization (WHO)/United Nations University. Energy and Protein Requirements. Report of a Joint Expert Consultation. Technical Report Series No. 724. Geneva: WHO, 1985.

26 Goldberg GR, Black AE, Jebb SA, Cole TJ, Murgatroyd PR, Coward WA, et al. Critical evaluation of energy intake data using fundamental principles of energy physiology: 1 . Derivation of cut-off limits to identify under-recording. European Journal of Clinical Nutrition 1991; 45: 569-81.

27 Black AE. Critical evaluation of energy intake using the Goldberg cut-off for energy intake:basal metabolic rate. A practical guide to its calculation, use and limitations. International Journal of Obesity and Related Metabolic Disorders 2000; 24: 1119-30.

28 Merrill AL, Watt BK. Agriculture Handbook No. 74, Energy Value of Foods. Washington, DC: United States Government Printing Office, 1973.

29 SAS Institute. SAS OnlineDoc ${ }^{\circledR}$, Version 8. Cary, NC: SAS Institute, 2002.

30 US Department of Agriculture, US Department of Health and Human Services. Nutrition and Your Health: Dietary Guidelines for Americans. Pueblo, CO: Consumer Information Center, 2000.

31 Kolonel LN, Henderson BE, Hankin JH, Nomura AMY, Wilkens LR, Pike MC, et al. A multiethnic cohort in Hawaii and Los Angeles: baseline characteristics. American Journal of Epidemiology 2000; 151: 346-57.

32 Huang MH, Schocken M, Block G, Sowers M, Gold E, Sternfeld $\mathrm{B}$, et al. Variation in nutrient intakes by ethnicity: results from the Study of Women's Health Across the Nation (SWAN). Menopause 2002; 9: 309-19.

33 Shimizu H. A Basic Report on Takayama Study. Gifu: Department of Public Health, University School of Medicine, 1996.

34 Wilkinson CE, Goldman JD, Cook A. Trends in food and nutrient intakes by adults: NFCS 1977-78, CSFII 1989-91, and CSFII 1994-95. Family Economics and Nutrition Review 1997; 10: 2-15.

35 Freire RD, Cardoso MA, Shinzato AR, Ferreira SR. Nutritional status of Japanese-Brazilian subjects: comparison across gender and generation. British Journal of Nutrition 2003; 89: 705-13. 
36 Anon. Nutritional Trends in Japan after World War 2. Tokyo: Daiichi Shuppan, 1998.

37 Subar AF, Krebs-Smith SM, Cook A, Kahle LL. Dietary sources of nutrients among US adults, 1989 to 1991. Journal of the American Dietetic Association 1998; 98: 537-47.

38 Kimira M, Nakatani Y, Takahashi T, Iidoi Y, Iwase Y, Kuriki T, et al. Research in methods used in health and nutrition evaluation of community nutrition planning [abstract]. Japanese Journal of Nutrition and Dietetics 2002; 60(Suppl. 5): 294.

39 Chessler SD, Fujimoto WY, Shofer JB, Boyko EJ, Weigle DS. Increased plasma leptin levels are associated with fat accumulation in Japanese Americans. Diabetes 1998; 47: $239-43$.

40 Ministry of Health, Labour and Welfare. The National Nutrition Survey in Japan, 2000. Tokyo: Daiichi Shuppan, 2002.

41 Shu XO, Jin F, Dai Q, Wen W, Potter JD, Kushi LH, et al. Soyfood intake during adolescence and subsequent risk of breast cancer among Chinese women. Cancer Epidemiology, Biomarkers \& Prevention 2001; 10: 483-8.
42 Wu AH, Wan P, Hankin J, Tseng CC, Yu MC, Pike MC. Adolescent and adult soy intake and risk of breast cancer in Asian-Americans. Carcinogenesis 2002; 23: 1491-6.

43 Deharveng G, Charrondiere UR, Slimani N, Southgate DA Riboli E. Comparison of nutrients in the food composition tables available in the nine European countries participating in EPIC. European Prospective Investigation into Cancer and Nutrition. European Journal of Clinical Nutrition 1999; 53 $60-79$.

44 Dai Q, Franke AA, Jin F, Shu XO, Hebert JR, Custer LJ, et al. Urinary excretion of phytoestrogens and risk of breast cancer among Chinese women in Shanghai. Cancer Epidemiology, Biomarkers \& Prevention 2002; 11: 815-21.

45 Kono S, Ahn YO. Vegetables, cereals and colon cancer mortality: long-term trend in Japan. European Journal of Cancer Prevention 2000; 9: 363-5.

46 Whittemore AS, Kolonel LN, Wu AH, John EM, Gallagher RP, Howe GR, et al. Prostate cancer in relation to diet, physical activity, and body size in blacks, whites, and Asians in the United States and Canada. Journal of the National Cancer Institute 1995; 87: 652-61.

\section{Appendix - List of food items in each food group}

\begin{tabular}{|c|c|c|}
\hline Food group & Food items in Gifu FFQ & Food items in Hawaii FFQ \\
\hline Grains & $\begin{array}{l}\text { Rice, potatoes, tubers, pasta, noodles, } \\
\text { unsweetened and sweetened breads, } \\
\text { toast, breakfast cereals }\end{array}$ & $\begin{array}{l}\text { Rice, potatoes, tubers, pasta, unsweetened and } \\
\text { sweetened breads, muffins, pancakes, waffles, } \\
\text { French toast, breakfast cereals, popcorn }\end{array}$ \\
\hline Fish & $\begin{array}{l}\text { Fresh fish, canned fish, dried fish, fish cakes, } \\
\text { shellfish, squid, shrimp, octopus, etc. }\end{array}$ & Fresh fish, canned fish, dried fish, shellfish \\
\hline Meats & $\begin{array}{l}\text { Beef, pork, ham, sausage, bacon, organ meats, } \\
\text { chicken }\end{array}$ & $\begin{array}{l}\text { Beef, veal, lamb, pork, organ meats, sausage, } \\
\text { bacon, luncheon meats, chicken, turkey }\end{array}$ \\
\hline Eggs & Eggs & Eggs \\
\hline Dairy products & $\begin{array}{l}\text { Milk, low-fat milk, yoghurt, skimmed milk, } \\
\text { probiotics, cheese, etc. }\end{array}$ & $\begin{array}{l}\text { Whole, low-fat and } 2 \% \text { milk, yoghurt, cheese, } \\
\text { cream, frozen desserts, dairy sauces, soups }\end{array}$ \\
\hline Vegetables & $\begin{array}{l}\text { Dark and light green vegetables, } \\
\text { yellow vegetables, tomatoes, } \\
\text { cruciferous vegetables, onion, mushrooms, } \\
\text { edible wild plants, etc. (excluding vegetable juices) }\end{array}$ & $\begin{array}{l}\text { Dark and light green vegetables, yellow vegetables, } \\
\text { tomatoes, cruciferous vegetables, onion, mushrooms, etc. } \\
\text { (excluding vegetable juices) }\end{array}$ \\
\hline Seaweed & Seaweed (e.g. wakame, nori, kombu, hijiki) & Seaweed (e.g. ogo limu, furikake) \\
\hline Fruits & Fruits (excluding fruit juice) & Fruits (excluding fruit juice) \\
\hline Soy products & $\begin{array}{l}\text { Tofu, miso, green soybeans, fried tofu } \\
\text { (abura-age and ganmodoki or nama-age), } \\
\text { dried tofu, natto, houba-miso, soybean milk }\end{array}$ & $\begin{array}{l}\text { Tofu, miso, fried tofu, tau foo kwa or tofu gan, } \\
\text { soybean sprouts, foojook or tofu skin, } \\
\text { western vegetarian meats, soybean drink or milk, } \\
\text { green soybeans, other soy products }\end{array}$ \\
\hline
\end{tabular}

FFQ - food-frequency questionnaire. 